\title{
The Distributions of helium isotopes and tritium along the U.S. GEOTRACES North Atlantic Sections (GEOTRACES GAO3)
}

\author{
W.J. Jenkins ${ }^{1}$,D.E. Lott III' ${ }^{2}$,B.E. Longworth ${ }^{2}$ \\ J.M. Curtice ${ }^{2}$ and K.L. Cahill ${ }^{2}$
}

\begin{abstract}
:
We present the distributions of helium isotopes (in the form of helium isotope ratio anomaly relative to the atmospheric ratio) and tritium along two sections occupied in the subtropical North Atlantic as part of the first U.S. GEOTRACES survey (GEOTRACES GA03). The general distributions of these isotopes are consistent with the continuing penetration and evolution of bomb-produced tritium and its daughter isotope ${ }^{3} \mathrm{He}$ in the main thermocline and along the western boundary current system. We combine these two distributions to compute a tritium- ${ }^{3} \mathrm{He}$ age, which is related to the elapsed time since the water was at the ocean surface. Although it is an indicator biased by the effects of mixing and influenced by the time history and spatial distribution of bomb tritium delivery to the ocean surface, it still remains a useful measure of ventilation time-scales. Aside from the continued propagation of the tritium $-{ }^{3} \mathrm{He}$ transient into the ocean interior, there are three notable features of interest in these distributions. The first is the clear signature of upwelling in the water column near the coast of Mauritania, characterized by the upward bowing of isochrones in the thermocline and discernable ${ }^{3} \mathrm{He}$ excess at the ocean surface. A simple ${ }^{3} \mathrm{He}$ mass balance calculation suggests an upwelling flux of order $1.8 \times 10^{6} \mathrm{~m}^{3} \mathrm{~s}^{-1}$ (1.8 Sv) along the Mauritanian coast. The second is a mid-depth ( 1500-2000 m) core of ventilated waters centered over the Mid-Atlantic Ridge, an anticyclonic circulation of waters likely originating in the Labrador Sea. The third notable feature is a volcanic ${ }^{3} \mathrm{He}$ plume at about $3500 \mathrm{~m}$ depth emanating from the TAG Hydrothermal Area that is detectable as much as $500 \mathrm{~km}$ away on each side of the Mid-Atlantic Ridge. We estimate a ${ }^{3} \mathrm{He}$ :heat ratio of $\sim 7 \times 10^{-18} \mathrm{~mol} \mathrm{~J}^{-1}$ and $\mathrm{a}^{3} \mathrm{He}$ flux from the TAG site of $\sim 15 \mathrm{mmol}^{-1}$. Since ${ }^{3} \mathrm{He}$ is a conserved tracer in the absence of measureable tritium, the correlation of volcanic ${ }^{3} \mathrm{He}$ with other hydrothermally influenced TEls (e.g., Fe) can be used as a dilution tracer as probe of nonconservative behavior in the water column. Also, since the regional and global fluxes of volcanic ${ }^{3} \mathrm{He}$ are known, the correlations can be used as a regional/global flux gauge for hydrothermal input of those TEls.
\end{abstract}

\section{Introduction:}

The GEOTRACES program identified a number of core Trace Elements and Isotopes (TEIs) that are considered key to achieving its main mission (Measures et al., 2007). In addition to those TEls, it was also recognized that the measurement of other ancillary properties and TEls would be of value for quantifying the rates and magnitudes of in situ processes that support, modify, or transform those primary TEls. The two isotopes ${ }^{3} \mathrm{H}$ (tritium) and ${ }^{3} \mathrm{He}$ prove of value for two reasons. The first is that tritium (Dockins et al., 1965; Giletti et al., 1958; Ostlund and Fine, 1979; Ostlund and Hut, 1984) and ${ }^{3} \mathrm{He}$

\footnotetext{
${ }^{1}$ Corresponding author, Woods Hole Oceanographic Institution, Woods Hole, MA 02543, USA Email: wjenkins@whoi.edu Tel: 001-508-289-2554

${ }^{2}$ Woods Hole Oceanographic Institution, Woods Hole, MA 02543, USA
} 
are useful transient tracers of ocean ventilation (e.g., Jenkins, 1988, 1998) and have been measured over a wide geographic scale (Jenkins, 1996). The two tracers can be combined to provide a Tritium $-{ }^{3} \mathrm{He}$ Age that is a measure of the elapsed time since a fluid parcel was in contact with the sea surface. Such an age, depending on location and tritium concentration, responds on timescales from as short as a few months to several decades. The tritium $-{ }^{3} \mathrm{He}$ age is biased by mixing and the temporal history and spatial pattern of the bomb tritium injection into the environment (Jenkins, 1980; Wunsch, 2002), but this bias can be accounted for quantitatively using the unique coupling of the two tracers, (Jenkins, 1987, 1988, 1998; Jenkins, 2004).

The second utility is that in the absence of measurable tritium, ${ }^{3} \mathrm{He}$ is a conservative tracer in the water column. Seafloor volcanic activity emits significant amounts of this isotope into the water column (Clarke et al., 1969), producing plumes of volcanic ${ }^{3} \mathrm{He}$ discernable over many thousands of kilometers in the deep ocean (Lupton, 1998; Lupton and Craig, 1981; Lupton et al., 2003), allowing estimates of the global flux of this isotope from newly forming oceanic crust using models of varying sophistication (Bianchi et al., 2010; Craig and Clarke, 1970; Farley et al., 1995). Using observed correlations between ${ }^{3} \mathrm{He}$ and $\mathrm{Fe}$, another hydrothermally augmented TEI, it is possible to make global estimates of hydrothermal Fe fluxes to the deep ocean (Boyle and Jenkins, 2008; Tagliabue et al., 2010). Such calculations assume a globally constant Fe: ${ }^{3} \mathrm{He}$ ratio, whereas recent observations suggest a significant difference in this ratio between fast- and slow-spreading ridges (Saito et al., 2013). One objective of the U.S. GEOTRACES North Atlantic sections was to sample ${ }^{3} \mathrm{He}$ and other TEls at and near another slowspreading ridge hydrothermal site, the TAG Hydrothermal Site at $26^{\circ} \mathrm{N}$ on the Mid Atlantic Ridge (Jenkins et al., 1980; Rona et al., 1975; Rona et al., 1984).

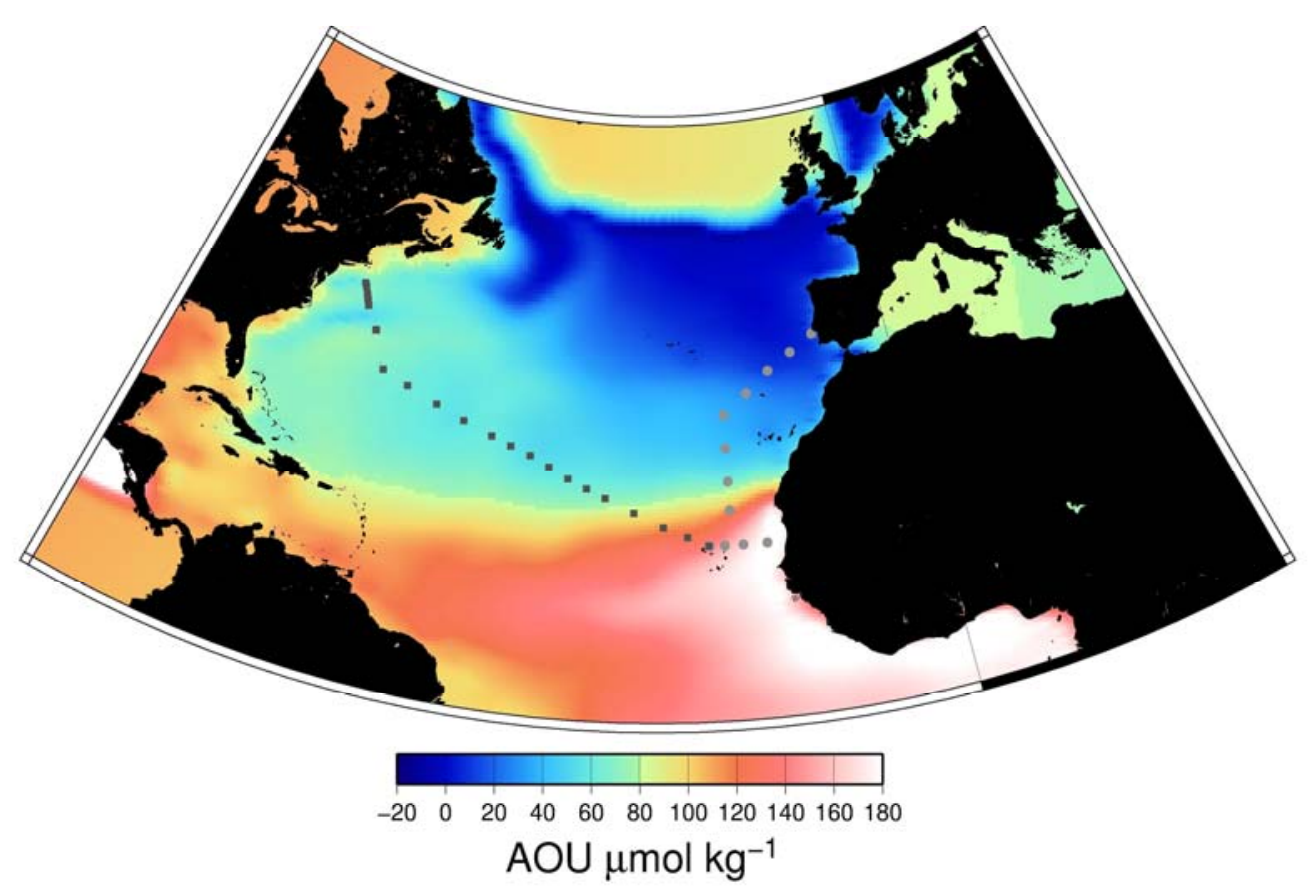

Figure 1: GEOTRACES station locations for the 2010 (filled circles) and 2011 (filled squares) campaigns plotted on apparent oxygen utilization on the $26.8 \mathrm{~kg} \mathrm{~m}^{-3}$ neutral surface. 
A description of the cruise, station locations, and water mass distributions exists as another paper in this special issue (Jenkins et al, 2014), but for reference we show the station locations in Figure 1, which are plotted against the distribution of apparent oxygen utilization ( $A O U$ ) on the $26.8 \mathrm{~kg} \mathrm{~m}^{-3}$ neutral surface, estimated using the World Ocean Atlas 2009 climatology (Garcia et al., 2010). Here, the 2010 stations are shown as filled gray circles, and the 2011 stations by darker gray squares. Note the overlap station sampled on both cruises at the TENATSO site $\left(17.4^{\circ} \mathrm{N} 24.5^{\circ} \mathrm{W}\right)$.

\section{Sampling and Measurement Methods}

Tritium and helium were sampled at all station locations (see Figure 1). Samples were drawn from a twelve position 30 liter Niskin rosette equipped with a Seabird SBE9+ CTD, SBE43 dissolved oxygen sensor, Seapoint SCF fluorometer, Wet Labs C-Star transmissometer, and Tritech LPRA-200 altimeter. All bottles were sampled for salinity, dissolved oxygen, and inorganic macronutrients. Helium samples were drawn using TYGON tubing into lengths of $5 / 8$ " soft copper refrigeration tubing and hydraulically crimpsealed using the technique described by Young and Lupton (1983). Tritium samples were drawn using TYGON tubing into especially baked and argon filled 1 liter flint glass bottles sealed with high density polyethylene caps. On shore, about $500 \mathrm{ml}$ of each tritium sample was introduced into 1 liter aluminosilicate glass flasks, degassed, and stored in a shielded underground area (to minimize cosmic ray exposure) for 6-12 months for ${ }^{3} \mathrm{He}$ ingrowth. The samples were then analyzed mass spectrometrically for the tritiugenic ${ }^{3} \mathrm{He}$ and the tritium concentrations computed. Results were typically measured to an accuracy of better than $0.5 \%$ in quadrature with counting statistics and a detection limit better than $0.005 \mathrm{TU}$ (one standard deviation). Results were corrected for a modest contribution (0.003 $\pm 0.002 \mathrm{TU}$ ) from cosmic ray spallation during storage. The helium samples were quantitatively extracted from the $\sim 45 \mathrm{~g}$ water stored in the crimped copper tubes using an all metal high vacuum system and the gases transferred $25 \mathrm{ml}$ aluminosilicate glass ampoules for storage prior to mass spectrometric measurement. The samples were then measured mass spectrometrically for the helium and neon concentration by ion beam manometry, and the helium isotope ratio measured relative to the atmospheric standard (Lott and Jenkins, 1984, 1998). Measurements of the helium and neon concentrations were made to an accuracy of approximately $0.5 \%$ ( $0.3 \%$ for helium and $0.55 \%$ for neon) and the helium isotope ratio was measured to better than $0.15 \%$ (one standard deviation of measurement). Corrections to the latter were made for a modest dependence of the apparent isotope ratio on sample size. The sizes of the corrections were everywhere less than one standard deviation of measurement. A finalized version of this data was submitted to the BCO-DMO and the data are to be included in the GEOTRACES Intermediate Data Product 2014 (Mawji, 2014).

\section{A General Description of the Distributions of Helium Isotopes and Tritium}

The distributions of these isotopes are shown in Figure 2 (tritium in the upper panel and $\delta^{3} \mathrm{He}$, the helium isotope ratio anomaly in the lower panel). The sections are presented in a manner identical to the hydrographic and water mass analysis results reported elsewhere in this issue (Jenkins et al, 2014). They are arranged such that an approximately zonal section extending southeastward from Cape Cod, North America to Mauritania, Africa is presented on the left, and an approximately meridional section extending from the Cape Verde Islands northward to Lisbon, Portugal is presented on the right. Where 

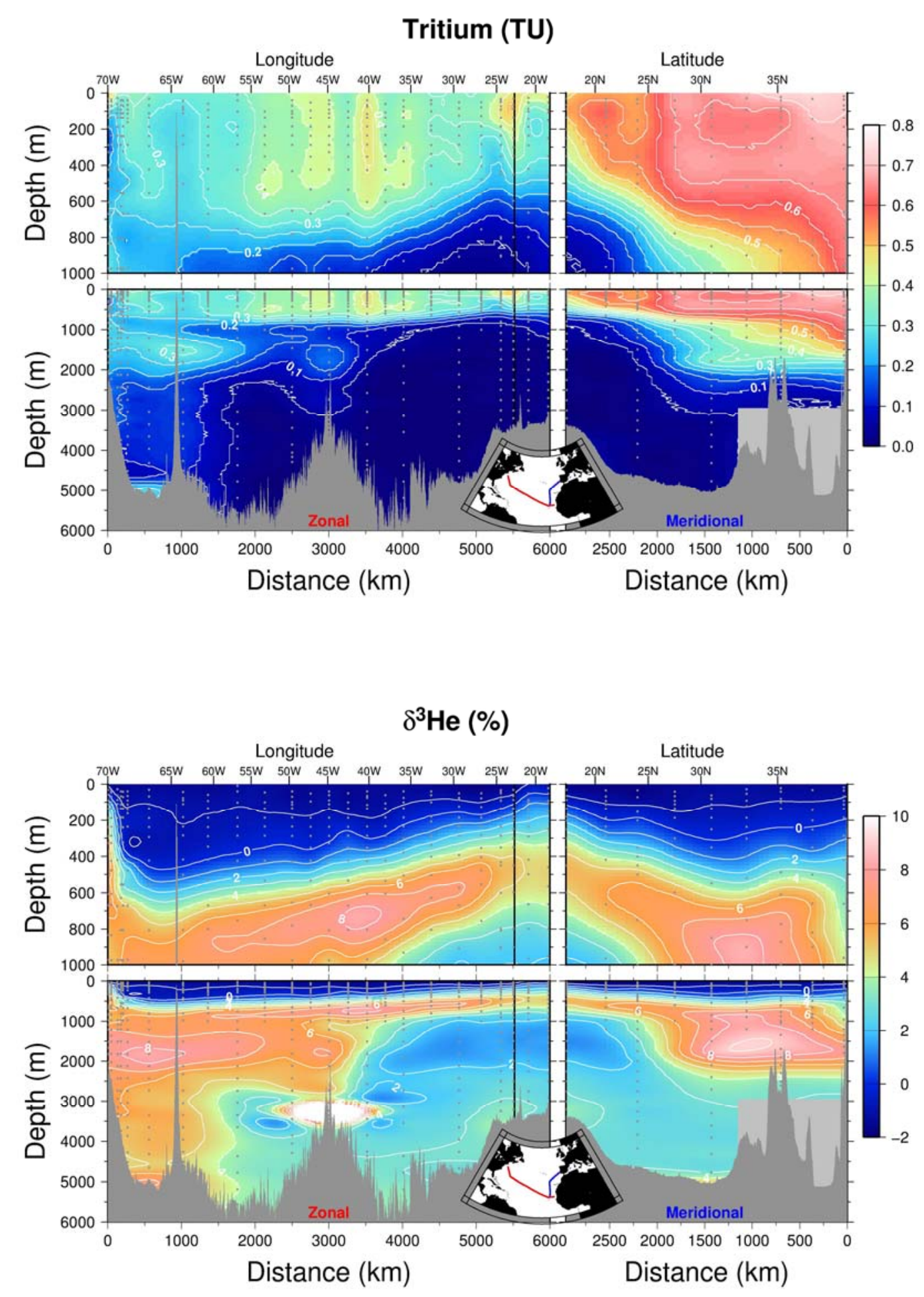

Figure 2: The distributions of tritium (upper panel in TU) and helium isotope ratio anomaly (lower panel, in percent) along two approximately zonal (left part of the sections) and meridional (right part of the sections). The tritium has been decay corrected to a common date (November 1, 2010).

the two sections meet is indicated by a black vertical line in the right-hand end of the "zonal" section. 
Full depth sections appear on the lower half of Figure 2 and an expanded scale for the upper $1000 \mathrm{~m}$ of the water column occurs on the upper half. The sample data points, indicated by gray dots in the plots, were objectively mapped onto a $50 \mathrm{~km}$ (horizontal) by $50 \mathrm{~m}$ (vertical) grid using D.I.V.A. (e.g., see Brasseur, 1996) with horizontal and vertical scale lengths of $1000 \mathrm{~km}$ and $500 \mathrm{~m}$ respectively. The resultant grids were mapped and contoured using GMT (see Wessel and Smith, 1998). Finally, the northernmost deep portions of the meridional sections (north of $\sim 32^{\circ} \mathrm{N}$ and deeper than $\sim 3000 \mathrm{~m}$ ) have been masked using a light gray rectangle because they contain no data.

Tritium concentrations are reported in Tritium Units (TU), which are defined as $10^{18}$ times the atom ratio of this isotope relative to the dominant hydrogen isotope. Because sampling was done over the course of two years (October-November 2010 and November-December, 2011) the tritium data in Figure 2 were decay-corrected to a common time (November 1, 2010). In the near surface, tritium is seen to penetrate from the north-eastern corner of the gyre with lower tritium waters apparent in the west. This is the influence of the entrainment of South Atlantic waters into the shallow North Atlantic subtropical gyre (Schmitz, 1995; Schmitz and McCartney, 1993) associated with the northward flowing limb of the planetary scale meridional overturning circulation (MOC). This is most pronounced in the Florida Current and Gulf Stream and influences the western portion of the Subtropical Gyre most strongly (see the shallow band of lower tritium waters in Figure 2 between approximately 55 and $65^{\circ} \mathrm{W}$ ). Southern hemispheric waters are characteristically low in tritium concentrations due to the much lower deposition of this isotope in the southern hemisphere (Butzin and Roether, 2004; Doney et al., 1992; Doney et al., 1993; Weiss and Roether, 1980) and strong upwelling in the southern ocean (ludicone et al., 2008; Kuhlbrodt et al., 2007; Olbers and Visbeck, 2005) of old, low tritium water. Between 65 and $25^{\circ} \mathrm{W}$ in the "zonal" section, the tritium concentrations in the upper $\sim 600 \mathrm{~m}$ appear banded, with 100 $\mathrm{km}$ scale variations of $\sim 0.100 \mathrm{TU}$, roughly 10-20 times measurement uncertainties (0.005 to 0.010 TU). This is a result of the interaction of the large scale zonal gradient in tritium (higher in the east) and alternating zonal flow. The latter is evident in the circulation scheme for the upper thermocline constructed by Schmitz and McCartney (1993; their Figure 9b). Specifically, near-surface currents just west and east of the Mid Atlantic Ridge along our cruise track derive predominantly from the northeast, while there is an apparent reversal (flow from the west) immediately over the ridge.

The pronounced tongue of higher tritium waters penetrating southward at a few hundred meters' depth in the meridional section traces the wind- and buoyancy-driven subduction (Federiuk and Price, 1984; Luyten et al., 1983) of higher tritium northern surface waters into the main thermocline, a feature observed also in the North Pacific (Fine et al., 1987; McPhaden and Fine, 1988). This southward penetration appears to detach from the African coast (see shallow maximum between 23 and $25^{\circ} \mathrm{W}$ in the zonal section), likely due to the influence of Atlantic Equatorial Water from the south (see Jenkins et al, 2014) and upwelling off the Mauritanian coast. Regarding the latter, note the upward bowing of tritium isopleths in the upper $600 \mathrm{~m}$ between the Cape Verde Islands and the Mauritanian coast

Deeper in the water column, there is significant penetration of tritium associated with the Mediterranean Water (in the northeast, between 1000 and 1500 m depth) and Labrador Sea Waters (in the northeast between 1500 and $2000 \mathrm{~m}$ depth, and in the west between 1000 and $2000 \mathrm{~m}$ depth). Note that there is a distinct tritium minimum at around $1000 \mathrm{~m}$ depth (visible mostly in the west, but 
extending across the entire zonal section) associated with tritium impoverished Antarctic Intermediate Water (AAIW). The minimum is more visible in the west due to contrast with underlying Labrador Sea Water. The contribution of AAIW is actually greater in the southeastern end of the section, but the deeper waters there are essentially tritium-free. Notably, the AAIW is not completely tritium-free; tritium concentrations in the salinity minimum are approximately $0.01 \mathrm{TU}$ in southwestern end of the section. Additionally, there is a tritium maximum centered over the Mid Atlantic Ridge at about $1600 \mathrm{~m}$ depth. The water mass analysis presented by Jenkins et al (2014) in this issue labels this water as predominantly Upper and Central Labrador Sea Waters in origin. The circulation scheme for this depth range is characterized by anticyclonic flow that likely acquires significant tritium by cross-frontal mixing with the subpolar gyre to the north.

Although the 0.05 TU isopleth bows upward on both sides of the Mid Atlantic Ridge, the deep and bottom waters west of the Ridge have measureable tritium concentrations, ranging from 0.01 to $0.03 \mathrm{TU}$ below $3000 \mathrm{~m}$ depth, with a westward/northward increase. This is consistent with the more rapid ventilation of the western basin by the deep western boundary undercurrents (Doney and Jenkins, 1994; Jenkins and Rhines, 1980; McCartney, 1992; Pickart and Hogg, 1989) that originate in the overflows between Great Britain and Greenland. Northwest of Bermuda, there is a significant tritium signal near the bottom associated with the deep overflow waters (Denmark Straits and IcelandScotland). Waters below $2500 \mathrm{~m}$ depth east of the Mid Atlantic Ridge are at or below detection limit, which is 0.002 to $0.003 \mathrm{TU}$. This is because this basin is ventilated from the south by tritium impoverished Antarctic Bottom Water (AABW) flowing through the Romanche Fracture Zone and by slow (century timescale) mixing of Iceland-Scotland Overflow water from the north (Schlitzer, 1987; Schlitzer et al., 1985).

We define the helium isotope ratio anomaly $\delta^{3} \mathrm{He}$ relative to the atmospheric standard:

$$
\delta^{3} \mathrm{He}=\left(\frac{\left({ }^{3} \mathrm{He} /{ }^{4} \mathrm{He}\right)_{X}}{\left({ }^{3} \mathrm{He} /{ }^{4} \mathrm{He}\right)_{\text {Air }}}-1\right) \times 100 \%
$$

where the subscript $X$ indicates the measured value. The $\delta^{3} \mathrm{He}$ distributions seen in Figure 2 (lower panel) are controlled in large part by the penetration of tritium into the water column, with two significant exceptions. The first is the fact that air-sea exchange drives the dissolved helium isotope ratio anomaly toward a solubility equilibrium value of approximately - $1.7 \%$ (Benson and Krause, 1980; Weiss, 1970 ) near the sea surface. The one deviation from this occurs off the Mauritanian coast, where the $\delta^{3} \mathrm{He}$ is elevated by approximately $1 \%$ above equilibrium (see Figure 3 ). This is a surface manifestation of upwelling. We can utilize this observed excess ${ }^{3} \mathrm{He}$ to estimate upwelling rates by assuming a mixedlayer balance. Using NCEP reanalysis data, a Schmidt number of 125 for He, and the gas exchange formulation proposed by Tsai and Liu (Tsai and Liu, 2003) for surfactant influenced waters, we compute an average piston velocity for the previous 3 weeks of $5.0 \mathrm{~m} \mathrm{~d}^{-1}$. This implies an ocean-atmosphere ${ }^{3} \mathrm{He}$ flux of $5 \%-\mathrm{m} \mathrm{d}^{-1}$. Given that this flux appears to extend $\sim 300 \mathrm{~km}$ off the coast, we estimate a ${ }^{3} \mathrm{He}$ flux of approximately $1.5 \times 10^{6} \%-\mathrm{m}^{3} \mathrm{~d}^{-1}$ per $\mathrm{m}$ of coast. The maximum $\delta^{3} \mathrm{He}$ observed in the water column is 
$\sim 5 \%$ at $600 \mathrm{~m}$ depth, which is $\sim 6.7 \%$ above equilibrium with the atmosphere. From this we can calculate an effective upwelling rate of $2.2 \times 10^{5} \mathrm{~m}^{3} \mathrm{~d}^{-1}$ per $\mathrm{m}$ coastline at that depth. Assuming this to be representative of the coast between Dakkar and Capo Blanco, this amounts to an upwelling of approximately $1.8 \mathrm{~Sv}$ for that region.

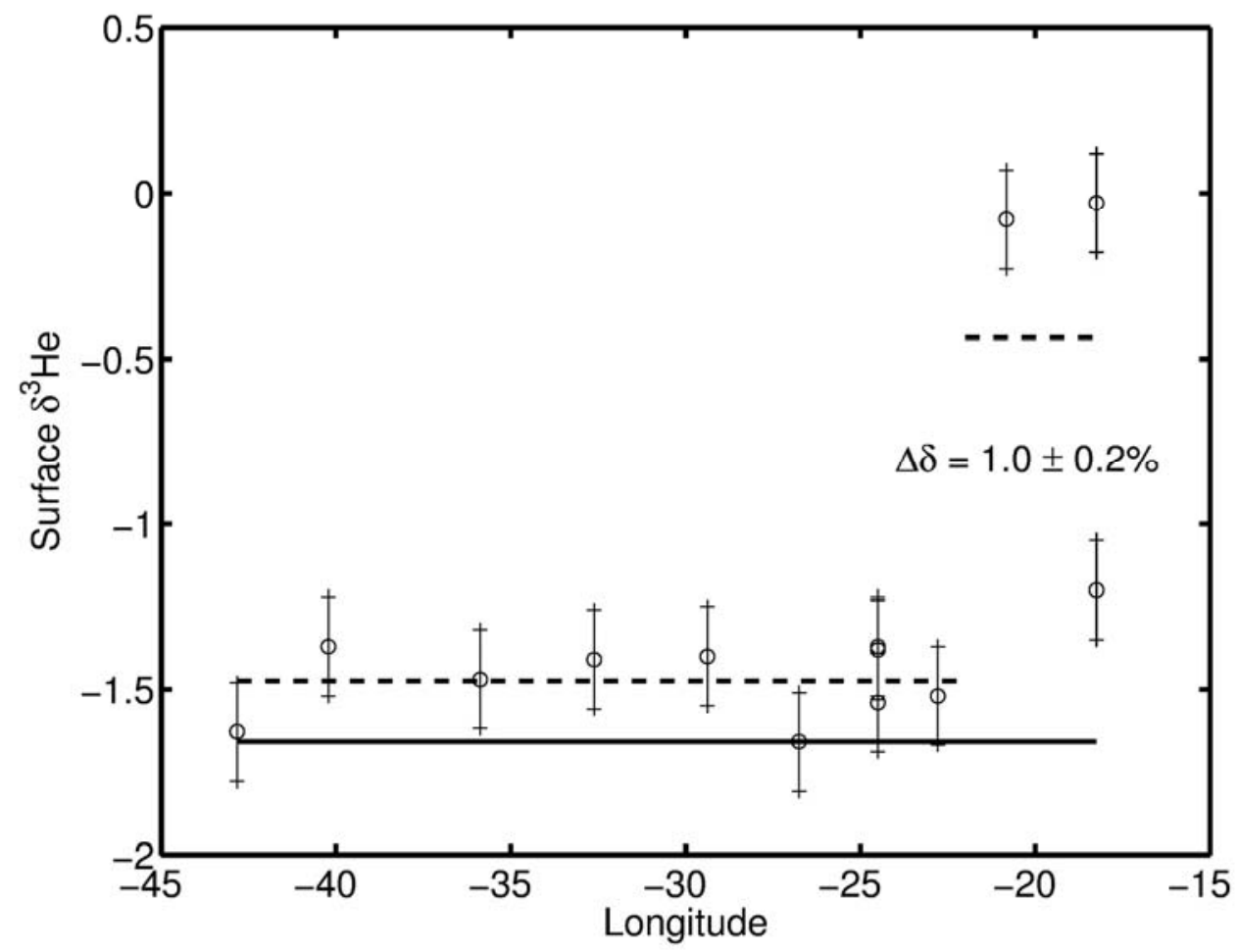

Figure 3: Measured $\delta^{3} \mathrm{He}$ in the upper $50 \mathrm{~m}$ as a function of longitude along the zonal section. The solid line is the expected isotope equilibrium value, the lower dashed line is the mean value west of $22^{\circ} \mathrm{W}$, and the upper dashed line is the mean east of $22^{\circ} \mathrm{W}$.

Descending through the thermocline, $\delta^{3} \mathrm{He}$ increases toward a maximum exceeding $8 \%$ at 600 to $900 \mathrm{~m}$ depth, generally below the depth at which tritium begins to decline steadily with depth. There is an additional $\delta^{3} \mathrm{He}$ maximum at intermediate depths ( $\left.1800 \mathrm{~m}\right)$ emanating from the western boundary, and is associated with intermediate depth tritium maximum that finds its origin in the Labrador Sea. Further to the south and east, there is a significant intermediate depth ( $1500 \mathrm{~m}) \delta^{3} \mathrm{He}$ minimum linked to the incursion of tritium impoverished waters from the south (notably AAIW and Upper Circumpolar Deep Water). West of $65^{\circ} \mathrm{W}$ below $4900 \mathrm{~m}, \delta^{3} \mathrm{He}$ also increases in association with a bottom tritium increase due to the influence of deep overflow waters from the north.

The second exception and most striking feature, however, is a strong $\delta^{3} \mathrm{He}$ maximum centered over the central rift valley of the Mid Atlantic Ridge. Here, the isotope ratio anomaly approaches $25 \%$ (see Figure 4) at the core of an approximately $500 \mathrm{~m}$ thick plume centered around $3300 \mathrm{~m}$ depth. Although the 
plume in Figure 2 appears to extend beyond the rift value walls and into the surrounding stations, this is solely an artifact of the mapping/gridding methods. We have plotted the helium isotope ratio anomaly interpolated onto a suitably referenced potential density anomaly surface $\left(\sigma_{3000}=41.484 \mathrm{~kg} \mathrm{~m}^{-3}\right.$ which corresponds to the core of the hydrothermal plume) against longitude in Figure 4.

Note that the vertical axis is logarithmic. A regional trend is sketched in with a dotted line in the figure. The conclusion to be drawn from Figure 4 is that although there is a gradual westward increase in $\delta^{3} \mathrm{He}$, likely due to the intrusion of tritium and tritiugenic ${ }^{3} \mathrm{He}$ in the deep western boundary current system (this is more clearly seen in the section shown in Figure 2 ) the western flank station at around $50^{\circ} \mathrm{W}$ is clearly elevated by as much as $1 \%$ relative to that trend. The fact that the hydrothermal ${ }^{3} \mathrm{He}$ influence appears only in the western flank station is likely a consequence of beta-plume dynamics associated with buoyancy injection (Stommel, 1982), which drives an inflow from eastern flank and topographically trapped flow along the median valley (Thurnherr et al., 2002). It extends beyond the plume height because the rift valley walls block westward flow and the "escape" of the "He to the west is limited to breaks in the wall. There may also be a contribution from shallower hydrothermal sites to the north, although this is purely speculative.

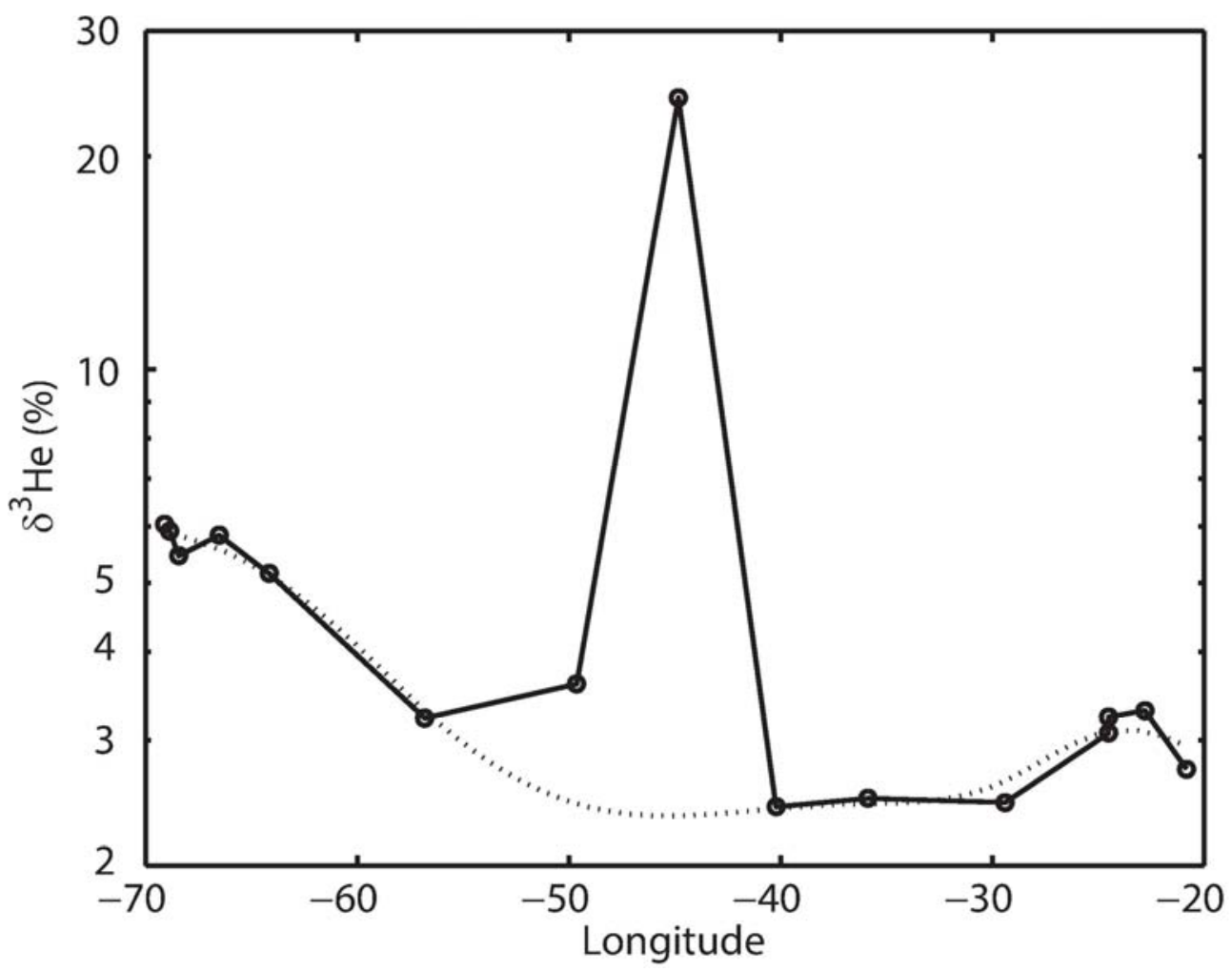

Figure 4: $\delta^{3} \mathrm{He}$ interpolated on the $\sigma_{3000}=41.484 \mathrm{~kg} \mathrm{~m}^{-3}$ potential density anomaly surface plotted as a function of longitude. This horizon corresponds closely to the TAG hydrothermal plume. Stations are connected by solid straight lines, while a dotted line showing the basin scale regional trend is shown for reference. Measurement errors are comparable to the size of the symbols. 
The CTD temperature profiles, when plotted against potential density anomaly referenced to 3000 decibars, show elevated temperatures in the Rift Valley compared to the flank stations (Figure 5). The maximum difference approaches $0.038^{\circ} \mathrm{C}$, with the greatest difference just above the seafloor. We interpret this to be the result of diffuse conductive heating through the seafloor as well as direct buoyancy injection. If we attribute approximately two thirds of the temperature increase to the latter process, using a specific heat capacity of $3.9 \times 10^{3} \mathrm{~J} \mathrm{Kg}^{-1} \mathrm{C}^{-1}$ we obtain a net heat injection into the plume of $\sim 100 \mathrm{~J} \mathrm{~kg}^{-1}$ at the plume maximum. Compared to the observed plume ${ }^{3} \mathrm{He}$ anomaly of $7.3 \times 10^{-16} \mathrm{~mol}$ $\mathrm{kg}^{-1}$, this yields a ${ }^{3} \mathrm{He}$ :heat ratio of $\sim 7 \times 10^{-18} \mathrm{~mol} \mathrm{~J}^{-1}$. This compares well with other estimates, e.g., ranging from $4 \times 10^{-18}$ (Lupton et al., 1989) to $9 \times 10^{-18} \mathrm{~mol} / \mathrm{J}$ (Jean-Baptiste et al., 2004). Monitoring of the central black smoker complex at the TAG site led Goto et al (2003) to estimate the power output of this field to be approximately $70 \mathrm{MW}$ with some temporal variation. Using our estimated ${ }^{3} \mathrm{He}$ :heat ratio we compute the ${ }^{3} \mathrm{He}$ output of this plume area to be $\sim 0.5 \mathrm{nmol} \mathrm{s}^{-1}$, or approximately $\sim 15 \mathrm{mmol} \mathrm{y}^{-1}$. Based on recent estimates of the global ${ }^{3} \mathrm{He}$ flux (Bianchi et al., 2010), we estimate this constitutes approximately $0.003 \%$ of the global input.

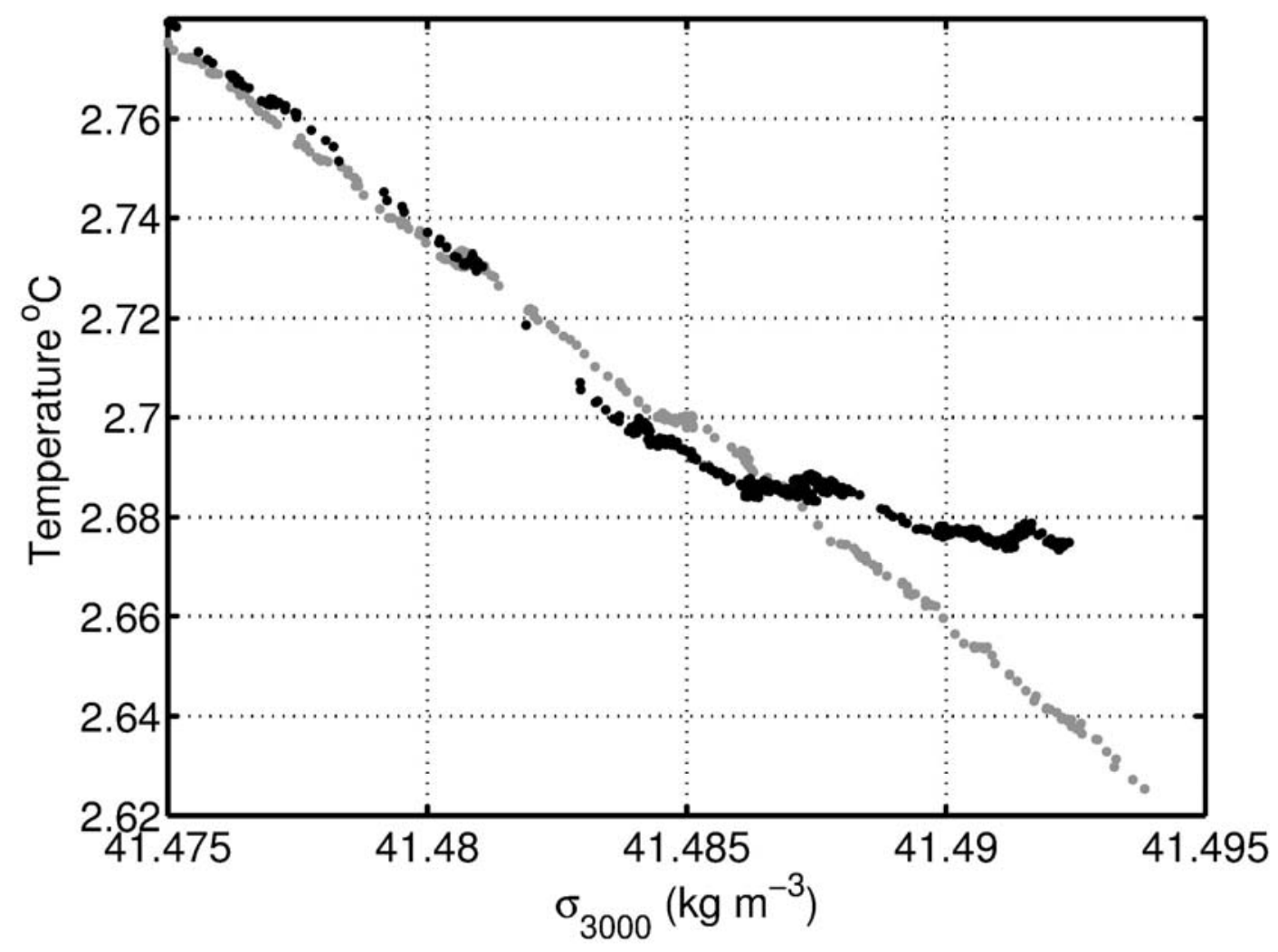

Figure 5: A plot of CTD temperature against potential density anomaly referenced to 3000 decibars for a flank station (gray dots) and the TAG plume station (black dots). 
Finally, correlating excess TEls (e.g., Fe) in the plume we can derive an estimate of the "raw" fluxes of these TEls into the water column. Between 2500 and $3300 \mathrm{~m}$ depth a significant excess ${ }^{3} \mathrm{He}$ signal relative to neighboring stations can be seen on the western flank station (black circles compared to the black squares in Figure 4, left panel). Given the small tritium concentrations observed for these locations and depths ( $\sim 0.03 \pm 0.01 \mathrm{TU})$, it is unlikely the observed differences $\left(\sim 1 \%\right.$ in $\left.\delta^{3} \mathrm{He}\right)$ are tritiugenic in origin. Thus it is possible that correlating TEls with ${ }^{3} \mathrm{He}$ may be used to estimate regional or even global fluxes of "stabilized" phases of these TEls, as has been done elsewhere (Boyle and Jenkins, 2008; Saito et al., 2013). This will be the subject of an upcoming paper.

\section{The Tritium ${ }^{3} \mathrm{He}$ Age}

The concentrations of tritium and excess ${ }^{3} \mathrm{He}$ may be combined to estimate a Tritium $-{ }^{3} \mathrm{He}$ Age , which can be loosely interpreted as the time elapsed since a fluid parcel was last at the sea surface:

$$
\tau=17.763 \log \left(1+\frac{\left[{ }^{3} \mathrm{He}\right]_{\text {Excess }}}{\left[{ }^{3} \mathrm{H}\right]}\right)
$$

where we use the accepted half-life of tritium (12.31 years, MacMahon, 2006) to compute the mean life in years, and both tritium and excess ${ }^{3} \mathrm{He}$ are in molar units. To compute the excess ${ }^{3} \mathrm{He}$ we use

$$
\left[{ }^{3} \mathrm{He}\right]_{\text {Excess }}=0.01\left(\delta^{3} \mathrm{He}-\delta^{3} \mathrm{He}^{*}\right) R_{A} C(\mathrm{He})
$$

where $\delta^{3} \mathrm{He}$ is the helium isotope ratio anomaly expressed in percent, $\delta^{3} \mathrm{He}^{*}$ is the solubility equilibrium helium isotope ratio anomaly (Benson and Krause, 1980), $\mathrm{R}_{\mathrm{A}}$ is the atmospheric ${ }^{3} \mathrm{He} /{ }^{4} \mathrm{He}$ ratio (Clarke et al., 1976), and $\mathrm{C}(\mathrm{He})$ is the concentration of helium in molar units. The tritium concentration in TU can be converted to molar units by multiplying by $1.1102 \times 10^{-16}(1-0.001 S)$, where $S$ is the salinity.

The tritium- ${ }^{3} \mathrm{He}$ age distributions are presented in Figure 6 . The major contour interval is 5 years, but in the shallow $(1000 \mathrm{~m}$ ) sections the 2, 4, 6, and 8 year isochrones are included as thin dotted lines. The age is within errors of zero at the surface with the exception of the Mauritanian upwelling region, where the surface ages are distinctly non-zero, and above $600 \mathrm{~m}$ depth the age isochrones bow upward. A feature that we don't fully understand is that this bowing occurs away from the coast and that the isochrones actually tilt downward into the most shoreward station. We speculate that this may be the influence of an along-shore flow. 


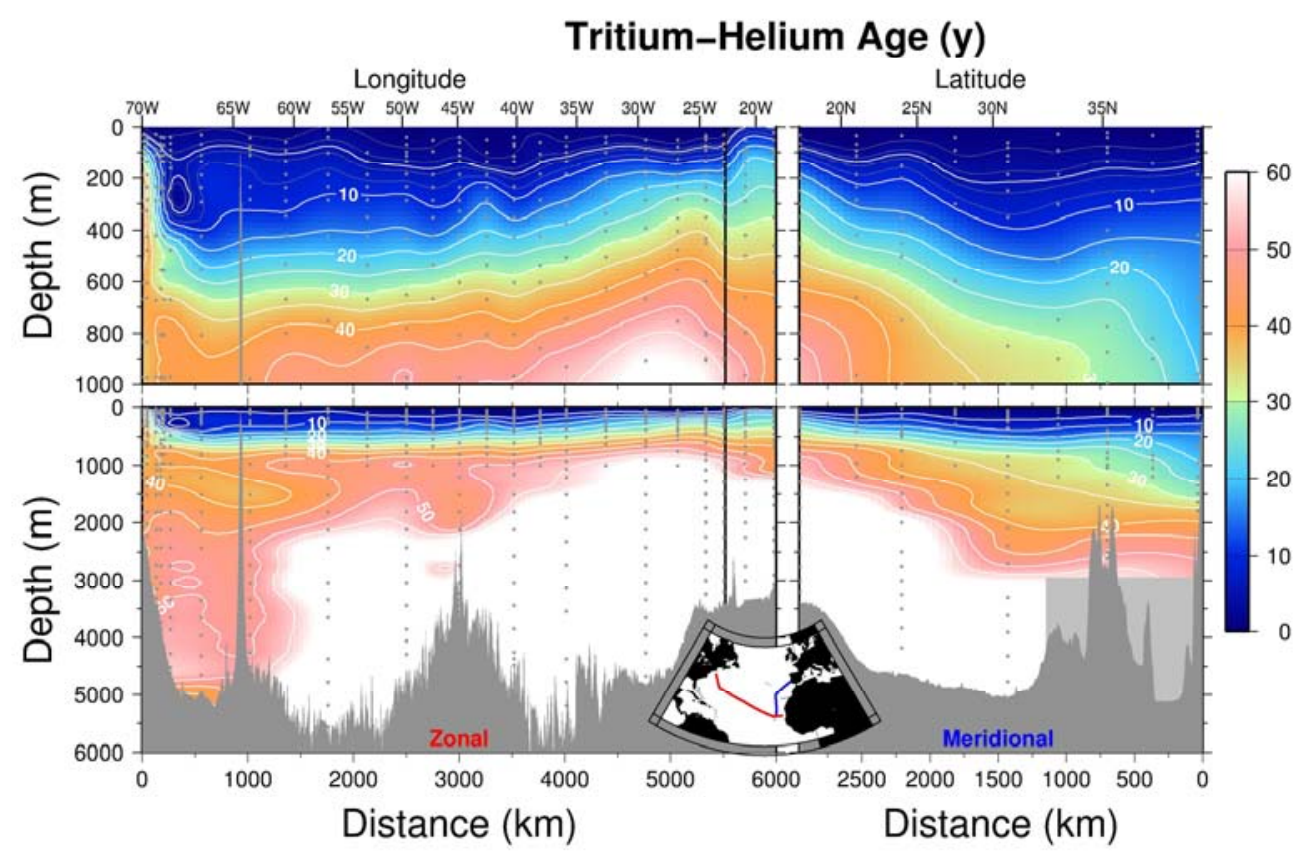

Figure 6: The computed Tritium ${ }^{3}$ He age distributions.

Before interpreting the thermocline tritium $-{ }^{3} \mathrm{He}$ ages more quantitatively, it is instructive to do a simple model comparison. We force an ensemble of simple box models with ventilation rates ranging from 1 to 100 years (see Jenkins, 1980) using a North Atlantic surface water tritium history proposed by Stanley et al (2012) from an initial condition of 0.5 T.U. at 1950 through 2011. In Figure 7 we compare the tritium${ }^{3} \mathrm{He}$ age computed from the evolved tritium and ${ }^{3} \mathrm{He}$ concentrations the ensembles in the model year 2011 with the "actual" (box model turnover) age. Although this is a rather crude approximation, analysis of tracer (both CFCs and tritium- ${ }^{3} \mathrm{He}$ ) distributions and their evolution in the North Atlantic thermocline and in numerical ocean models point to transit time distributions whose characteristic widths are comparable to their spreads (Peacock and Maltrud, 2006; Waugh et al., 2004), a feature that is not unlike our box model behavior for tritium- ${ }^{3} \mathrm{He}$ (Stanley et al., 2012).

It is notable that whereas there was a general tendency for the tritium-3He age to be biased low during the early years of the tritium-transient (Doney et al., 1997; Jenkins, 1980), the bias for intermediate time-scales (5-25 years) is now reversed. A rationale for this can be drawn from consideration of the advection-diffusion equations for the tritium-3He age (Jenkins, 1998) and the fact that we are now on the "back porch" of the transient. A broad conclusion to be drawn from this comparison is that the tritium- ${ }^{3} \mathrm{He}$ age is accurate to about $10-15 \%$ for timescales less than three decades, namely within the rough ventilation time-scales for the main thermocline. Thus it should be possible to use these ages to estimate TEI transformation rates. Clearly a more refined analysis using Transit time Distributions (TTD) 
with other transient tracers (CFCs and $\mathrm{SF}_{6}$ ) will yield more robust estimates. This will be the subject of a future paper.

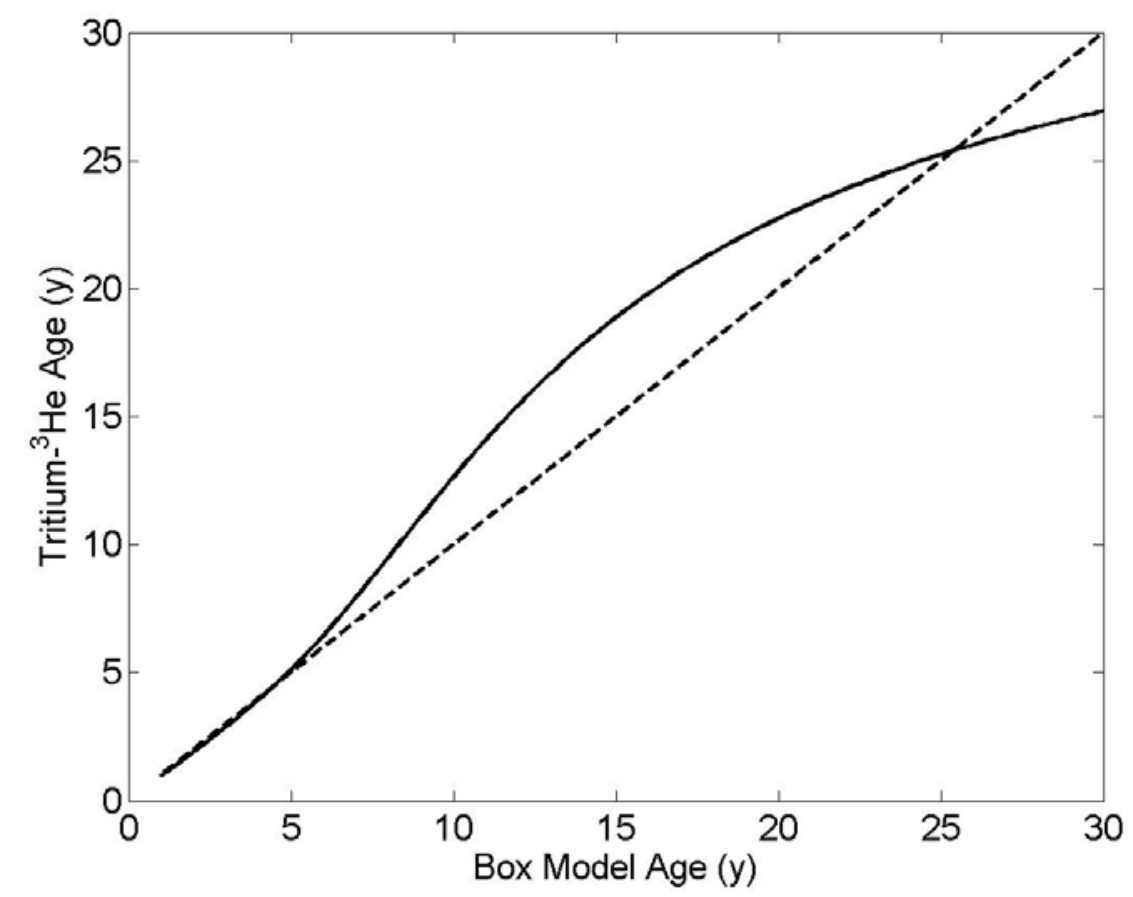

Figure 7: A comparison of tritium ${ }^{3} \mathrm{He}$ (solid line) vs. "actual" (dashed line) ages for a simple box model simulation.

Ages increase monotonically downward into and through the main thermocline. One notable geographic trend is the spreading of isochrones in the mode water regions (both the STMW near the western boundary current region and the Madeira Mode water formation area in the east. The ages of the water masses within these regions is consistent with the expected formation time-scales (i.e., the approximate volume of the water mass divided by how much is formed each year) (Joyce et al., 2013; Worthington, 1959).

Below the thermocline, there is a dramatic penetration of mid-depth isochrones in both the northern part of the meridional section (associated with the Mediterranean Water and Labrador Sea Water) and in the western boundary current region (associated with Labrador Seawater). We again remark on the extended age minimum over the Mid Atlantic Ridge at 1500-2000 m depth linked to the tritium maximum with an intermediate depth anticyclonic flow influenced by entrained Labrador Sea Water. Note also the decrease in age with depth below $4500 \mathrm{~m}$ west of Bermuda. This is associated with increases in tritium, tritiugenic ${ }^{3} \mathrm{He}$, and CFCs, likely the influence of the deep overflow waters. 


\section{Summary and conclusions}

We presented the observed distributions of tritium and $\delta^{3} \mathrm{He}$ along the 2010-2011 U.S. GEOTRACES sections in the North Atlantic, and explain their large-scale characteristics in terms of the evolving bomb-tritium transient in conjunction with what is known about the ventilation and circulation of this ocean basin. The primary features of these distributions are consistent with what is known about North Atlantic circulation and ventilation, but there are a number of notable aspects, including:

- Surface elevated $\delta^{3} \mathrm{He}$ and upward bowing thermocline isochrones in the Mauritanian upwelling region

- Significant intermediate depth penetration of tritium and tritiugenic ${ }^{3} \mathrm{He}$ associated with Labrador Sea Waters

- Evidence (including elevated tritium and lower tritium- ${ }^{3} \mathrm{He}$ age) of an anticyclonic flow centered along the Mid Atlantic Ridge at a depth of 1500-2000 m influenced by Labrador Sea Water

- A strong $\delta^{3} \mathrm{He}$ plume (approaching $25 \%$ in magnitude) over the TAG hydrothermal site, with a characteristic ${ }^{3} \mathrm{He}$ :heat ratio of $7 \times 10^{-18} \mathrm{~mol} \mathrm{~J}^{-1}$, and evidence of a small corresponding anomaly $500 \mathrm{~km}$ away on the western flank

- A clear bomb-tritium (and tritiugenic ${ }^{3} \mathrm{He}$ ) signature in the western boundary current region

\section{Acknowledgements}

We thank the Captain and crew of the R/V KNORR for their support and cooperation during two very challenging voyages. Hydrographic measurements were made by hard-working people from the Ocean Data Facility at Scripps Institute of Oceanography, specifically Susan Becker, Melissa Miller, Courtney Schatzmann, and Rob Palomares. Mary C. Johnson played an important role in assembling and managing the data aboard the ship, and with QA/QC on shore. We thank an anonymous reviewer for valuable criticism and suggestions regarding the hydrothermal ${ }^{3} \mathrm{He}$-heat calculations and discussion. We are grateful to Don Rice (NSF) for his efforts and support. This work was funded by the National Science Foundation under Grant No. OCE-0926659. 


\section{References}

Benson, B.B., Krause, D., Jr., 1980. Isotopic fractionation of helium during solution: a probe for the liquid state. Journal of Solution Chemistry 9, 895-909.

Bianchi, D., Sarmiento, J.L., Gnanadesikan, A., Key, R.M., Schlosser, P., Newton, R., 2010. Low helium flux from the mantle inferred from simulations of oceanic helium isotope data. Earth and Planetary Science Letters 297, 379-386.

Boyle, E., Jenkins, W.J., 2008. Hydrothermal iron in the deep western South Pacific. Geochimica et Cosmochimica Acta 72, A107.

Brasseur, P., Beckers, J.M., Brankart, J.M., Schoenauen, R., 1996. Seasponal temperature and salinity fields in the Mediterranean Sea: Climatological analyses of a historical data set. Deep Sea Research Part I: Oceanographic Research Papers 43, 159-192.

Butzin, M., Roether, W., 2004. The tritium budget of the South Atlantic. Journal of Geophysical Research 109, 003036.

Clarke, W.B., Beg, M.A., Craig, H., 1969. Excess ${ }^{3} \mathrm{He}$ in the sea: evidence for terrestrial primordial helium. Earth and Planetary Science Letters 6, 213-220.

Clarke, W.B., Jenkins, W.J., Top, Z., 1976. Determination of tritium by spectrometric measurement of ${ }^{3} \mathrm{He}$. International Journal of Applied Radiation and Isotopes 27, 515-525.

Craig, H., Clarke, W.B., 1970. Oceanic ${ }^{3} \mathrm{He}$ : contribution from cosmogenic tritium. Earth and Planetary Science Letters 9, 45-48.

Dockins, K.O., Bainbridge, A.E., Houtermans, J.C., Suess, H.E., 1965. Tritium in the mixed layer of the North Pacific Ocean. IAEA Tech Doc SM-87/54, 129-141.

Doney, S.C., Glover, D.M., Jenkins, W.J., 1992. A model function of the global bomb-tritium distribution in precipitation, 1960-1986. Journal of Geophysical Research 97, 5481-5492.

Doney, S.C., Jenkins, W.J., 1994. Ventilation of the deep western boundary current and abyssal Western North Atlantic: Estimates from tritium and 3He distributions. Journal of Physical Oceanography 24, 638-659.

Doney, S.C., Jenkins, W.J., Bullister, J.L., 1997. A comparison of ocean tracer dating techniques on a meridional section in the eastern North Atlantic. Deep-Sea Research I 44, 603-626.

Doney, S.C., Jenkins, W.J., Ostlund, H.G., 1993. A tritium budget for the North Atlantic. Journal of Geophysical Research 98, 18069-18081.

Farley, K.A., Maier-Reimer, E., Schlosser, P., Broecker, W.S., 1995. Constraints on mantle ${ }^{3} \mathrm{He}$ fluxes and deep-sea circulation from a general circulation model. Journal of Geophysical Research 100, 3829-3839.

Federiuk, J.M., Price, J.F., 1984. Subduction mechanisms in the eastern North Atlantic. Transactions of the American Geophysical Union 65, 943.

Fine, R.A., Peterson, W.H., Ostlund, H.G., 1987. The penetration of tritium into the tropical Pacific. Journal of Physical Oceanography 17, 553-564.

Garcia, H.E., Locarnini, R.A., Boyer, T.P., ANtonov, J.I., Baranova, O.K., Zweng, M.M., Johnson, D.R., 2010. Volume 3: Dissolved Oxygen, Apparent Oxygen Utilization, and Oxygen Saturation. U.S. Government Printing Office, Washington, D.C.

Giletti, B.J., Bazan, F., Kulp, J.L., 1958. The geochemistry of tritium. Transactions of the American Geophysical Union 39, 807-818.

Goto, S., Kinoshita, M., Schultz, A., Von Herzen, R.P., 2003. Estimate of heat flux and its temporal variation at the TAG hydrothermal mound, Mid-Atlantic Ridge $26 \mathrm{~N}$. Journal of Geophysical Research 108, doi:10.1029/2001JB000703.

Iudicone, D., Speich, S., Madec, G., Blanke, B., 2008. The global conveyor belt from the Southern Ocean perspective. Journal of Physical Oceanography 38, 1401-1425. 
Jean-Baptiste, P., Fourré, E., Charlou, J.-L., German, C.R., Radford-Knoery, J., 2004. Helium isotopes at the Rainbow hydrothermal site (Mid-Atlantic Ridge, $36^{\circ} 14 \mathrm{~N}$ ). Earth and Planetary Science Letters 221, 325-335.

Jenkins, W.J., 1980. Tritium and 3He in the Sargasso Sea. Journal of Marine Research 38, 533-569. Jenkins, W.J., 1987. ${ }^{3} \mathrm{H}$ and ${ }^{3} \mathrm{He}$ in the Beta Triangle: Observations of gyre ventilation and oxygen utilization rates. Journal of Physical Oceanography 17, 763-783.

Jenkins, W.J., 1988. The use of anthropogenic tritium and $3 \mathrm{He}$ to study subtropical gyre ventilation and circulation. Philosophical Transactions of the Royal Society (London) A325, 43-61.

Jenkins, W.J., 1996. Tritium and ${ }^{3} \mathrm{He}$ in the WOCE Pacific program. International WOCE Newsletter 23, 68.

Jenkins, W.J., 1998. Studying Thermocline Ventilation and Circulation Using Tritium and 3He. Journal of Geophysical Research 103, 15817-15831.

Jenkins, W.J., 2004. Tracers of Ocean Mixing in: Elderfield, H. (Ed.), The oceans and marine geochemistry, 1 ed. Elsevier, pp. 223-246.

Jenkins, W.J., Rhines, P.B., 1980. Tritium in the deep North Atlantic Ocean. Nature 286, 877-880.

Jenkins, W.J., Rona, P.A., Edmond, J.M., 1980. Excess ${ }^{3} \mathrm{He}$ in the deep-water over the Mid-Atlantic Ridge at $26^{\circ} \mathrm{N}$ : Evidence of hydrothermal activity. Earth and Planetary Science Letters 50, 39-44.

Joyce, T.M., Thomas, L.N., Dewar, W.K., Girton, J.B., 2013. Eighteen Degree Water formation within the Gulf Stream during CLIMODE. Deep Sea Research Part II: Topical Studies in Oceanography 91, 110.

Kuhlbrodt, T., Griesel, A., Montoya, M., Levemann, A., Hofmann, M., Rahmstorf, S., 2007. On the driving processes of the Atlantic meridional overturning circulation. Reviews of Geophysics 45, doi:10.1029/2004RG000166.

Lott, D.E., Jenkins, W.J., 1984. An automated cryogenic charcoal trap system for helium isotope mass spectrometry. Review of Scientific Instruments 55, 1982-1988.

Lott, D.E., Jenkins, W.J., 1998. Advances in the analysis and shipboard processing of tritium and helium samples. International WOCE Newsletter 30, 27-30.

Lupton, J.E., 1998. Hydrothermal helium plumes in the Pacific Ocean. Journal of Geophysical Research 103, 15853-15868.

Lupton, J.E., Baker, E.T., Massoth, G.J., 1989. Variable $3 \mathrm{He} /$ heat ratios in submarine hydrothermal systems: evidence from two plumes over the Juan de Fuca ridge. Nature 337, 161-164.

Lupton, J.E., Craig, H., 1981. A major helium-3 source at 15 S on the East Pacific Rise. Science 214, 13-18.

Lupton, J.E., Pyle, D.G., Jenkins, W.J., Greene, R., Evans, L., 2003. Evidence for an extensive hydrothermal plume in the Tonga-Fiji region of the South Pacific. Geochemistry, Geophysics, Geosystems 5, Q01003.

Luyten, J.R., Pedlosky, J., Stommel, H., 1983. The ventilated thermocline. Journal of Physical Oceanography 13, 292-309.

MacMahon, D., 2006. Half-life evaluations for ${ }^{3} \mathrm{H},{ }^{90} \mathrm{Sr}$, and ${ }^{90} \mathrm{Y}$. Applied Radiation and Isotopes 54, $1417-$ 1419.

Mawji, E.a.o., 2014. GEOTRACES Intemediate Data Product 2014. http://www.bodc.ac.uk/geotraces/data/idp2014/

McCartney, M.S., 1992. Recirculating components to the deep boundary current of the northern North Atlantic. Progress in Oceanography 29, 283-383.

McPhaden, M.J., Fine, R.A., 1988. A dynamical interpretation of the tritium maximum in the central Equatorial Pacific. Journal of Physical Oceanography 18, 1454-1457.

Measures, C., Henderson, G.M., Anderson, R.F., Adkins, J.F., Andersson, P., Boyle, E.A., Cutter, G., de Barr, H.J.W., Francois, R., Orians, K., Gamo, T., German, C.R., Jenkins, W.J., Moffett, J., Jeanel, C., Jickells, T.D., Krishnaswami, S., Mackey, D., Masque, P., Moore, J.K., Oschlies, A., Pollard, R.T., 
Rutgers van der Loeff, M.M., Sharma, M., Von Damm, K., Zhang, J., 2007. GEOTRACES - an international study of the global marine biogeochemical cycles of trace elements and their isotopes. Chemie der Erde 67, 85-131.

Olbers, D., Visbeck, M., 2005. A model of the zonally averaged stratification and overturning in the Southern Ocean. Journal of Physical Oceanography 35, 1190-1205.

Ostlund, H.G., Fine, R.A., 1979. Oceanic distribution and transport of tritium. Behaviour of tritium in the environment IAEA-SM-232/67, 303-314.

Ostlund, H.G., Hut, G., 1984. Arctic Ocean water mass balance from isotope data. Journal of Geophysical Research 89, 6373-6381.

Peacock, S., Maltrud, M.E., 2006. Transit-time distributions in a global ocean model. Journal of Physical Oceanography 36, 474-495.

Pickart, R.S., Hogg, N.G., 1989. A tracer study of the deep Gulf Stream cyclonic recirculation. Deep-Sea Research 36, 935-956.

Rona, P.A., McGregor, B.A., Betzer, P.R., Bolger, G.W., Krause, D., Jr., 1975. Anomalous water temperatures over Mid-Atlantic Ridge crest at 26 North latitude. Deep-Sea Research 22, 611618.

Rona, P.A., Thompson, G., Mottl, M.J., Karson, A., Jenkins, W.J., Graham, D.W., Mallette, M., Von Damm, K., Edmond, J.M., 1984. Hydrothermal activity at the TAG hydrothermal field, Mid-Atlantic Ridge crest at $26^{\circ} \mathrm{N}$. Journal of Geophysical Research 89, 11365-11377.

Saito, M.A., Noble, A.E., Tagliabue, A., Goepfert, T.J., Lamborg, C.H., Jenkins, W.J., 2013. Slow-spreading submarine ridges in the South Atlantic as a significant oceanic iron source. Nature Geoscience 6, 775-779.

Schlitzer, R., 1987. Renewal rates of East Atlantic Deep Water estimated by inversion of ${ }^{14} \mathrm{C}$ data. Journal of Geophysical Research 92, 2953-2969.

Schlitzer, R., Roether, W., Weidmann, U., Kalt, P., Loosli, H.H., 1985. A meridional ${ }^{14} \mathrm{C}$ and ${ }^{39} \mathrm{Ar}$ section in the Northeast Atlantic Deep Water. Journal of Geophysical Research 90, 6945-6952.

Schmitz, W.J., Jr., 1995. On the interbasin-scale thermohaline circulation. Reviews of Geophysics 33, 151-171.

Schmitz, W.J., Jr., McCartney, M.S., 1993. On the North Atlantic circulation. Reviews of Geophysics 31, 29-49.

Stanley, R.H.R., Doney, S.C., Jenkins, W.J., Lott, D.E.I., 2012. Apparent oxygen utilization rates calculated from tritium and helium-3 profiles at the Bermuda Atlantic Time-series Study site.

Biogeosciences 9, 1969-1983.

Stommel, H., 1982. Is the South Pacific helium-3 plume dynamically active? Earth and Planetary Science Letters 61, 63-67.

Tagliabue, A., Bopp, L., Dutay, J.-C., Bowie, A.R., Chever, F., Jean-Baptiste, P., Bucciarelli, E., Lannuzel, D., Remenyi, T., Sarthou, G., Aumont, O., Gehlen, M., Jeandel, C., 2010. Hydrothermal contribution to the oceanic dissolved iron inventory. Nature Geoscience 3, 252-256.

Thurnherr, A.M., Richards, K.J., German, C.R., Lane-Sherff, G.F., Speer, K.G., 2002. Flow and mixing in the rift valley of the Mid-Atlantic Ridge. Journal of Physical Oceanography 32, 1763-1778.

Tsai, W.-T., Liu, K.-K., 2003. An assessment of sea surface surfactant on the global atmosphere-ocea $\mathrm{CO}_{2}$ flux. Journal of Geophysical Research 108, 3127.

Waugh, D.W., Haine, T.W.N., Hall, T.M., 2004. Transport times and anthropogenic carbon in the subpolar North Atlantic Ocean. Deep-Sea Research I 51, 1475-1491.

Weiss, R.F., 1970. Helium isotope effect in solution in water and seawater. Science 168, 247-248.

Weiss, W.M., Roether, W., 1980. The rates of tritium input to the world oceans. Earth and Planetary Science Letters 49, 435-446. 
Wessel, P., Smith, W.H.F., 1998. New, improved version of Generic Mapping Tools released. EOS Transactions AGU 79, 579.

Worthington, L.V., 1959. The 18 degree water in the Sargasso Sea. Deep-Sea Research 5, 297-305.

Wunsch, C., 2002. Oceanic age and transient tracers: analytical and numerical solutions. Journal of Geophysical Research 107, 3048.

Young, C., Lupton, J.E., 1983. An ultratight fluid sampling system using cold-welded copper tubing. EOS Transactions AGU 64, 735. 